\title{
EVALUASI KEBIJAKAN PROGRAM MOBILE PUSAT LAYANAN INTERNET KECAMATAN (MPLIK)
}

\author{
Mulyono Yalia \\ Balai Pengkajian dan Pengembangan Komunikasi dan Informatika Bandung (BPPKI) Bandung \\ Jl.Pajajaran No.88 Bandung- 40173, Jabar, Telp.022-6017493, Fax.022-6021740, HP.081214519830, \\ email: mulyonoyalia@gmail.com \\ Naskah diterima tanggal 28 Oktober 2013, disetujui pada tanggal 20 November 2013
}

\section{POLICY EVALUATION OF DISTRICT MOBILE INTERNET SERVICE CENTER PROGRAM (MPLIK)}

\begin{abstract}
The research was motivated by a problem that is interesting to study the Provision of Facilities Policy Evaluation Program Universal Service Obligation (USO) Internet Service Center District Mobile Program (MPLIK) In Kuningan regency of West Java. The problem is how the Department of Communication and Information Policy in the Kuningan District MPLIK program in Kuningan District,? The aim is (1) want to know the Department of Communication and Information Policy in the Kuningan district MPLIK program in Kuningan district, (2) What factors are a supporter and obstacles in the implementation of policies in support of the Office of Communications and Informatics Program at Kabupaten MPLIK Brass, (3) Efforts effort whether carried out in the implementation of policies in support of the program Diskominfo MPLIK in Kuningan regency. The theory used as an approach to the problem of this research is the Evaluation of Policies Bardach. The research method used is a qualitative method of data collection techniques through participant observation and in-depth interviews. The results showed that in the Provision of Facilities Policy Evaluation Program USO MPLIK In Kuningan West Java through policy evaluation approach found another dimension, namely the importance of control, supervision, and coordination in addition to the four main dimensions of the policy evaluation is used as the approach in this study.
\end{abstract}

Keywords: evaluation, policy, Internet Service Centre District mobile (MPLIK).

\begin{abstract}
Abstrak
Penelitian ini dilatarbelakangi oleh masalah yang menarik untuk diteliti yaitu Evaluasi Kebijakan Penyediaan Fasilitas Universal Service Obligation (USO) Program Mobile Pusat Layanan Internet Kecamatan (MPLIK) Di Kabupaten Kuningan Jabar. Permasalahannya adalah bagaimanakah kebijakan Diskominfo Kabupaten Kuningan terhadap fasilitas USO program MPLIK di Kabupaten Kuningan? Tujuannya adalah (1) ingin mengetahui Kebijakan Diskominfo Kabupaten Kuningan terhadap program MPLIK di Kabupaten Kuningan, (2) Faktor-faktor yang menjadi pendukung dan penghambat dalam pelaksanaan kebijakan Diskominfo dalam mendukung Program MPLIK di Kabupaten Kuningan, (3) Upaya-upaya yang dilaksanakan untuk melaksanakan kebijakan Diskominfo dalam mendukung program MPLIK di Kabupaten Kuningan. Teori yang dipakai sebagai pendekatan terhadap masalah penelitian ini adalah Evaluasi Kebijakan dari Bardach. Metode penelitian yang digunakan adalah metode kualitatif
\end{abstract}


dengan teknik pengumpulan data melalui observasi partisipan dan wawancara mendalam. Hasil penelitian menunjukkan bahwa dalam evaluasi kebijakan penyediaan fasilitas USO program MPLIK di Kabupaten Kuningan Jabar melalui pendekatan evaluasi kebijakan ditemukan dimensi lain yaitu pentingnya pengendalian, pengawasan, dan koordinasi selain ke empat dimensi pokok evaluasi kebijakan tersebut yang dijadikan sebagai pendekatan di dalam penelitian ini.

Kata kunci: evaluasi, kebijakan, Mobile Pusat Layanan Internet Kecamatan (MPLIK).

\section{PENDAHULUAN}

Kesenjangan informasi di masyarakat masih sangat besar dirasakan terutama jika dibandingkan antara masyarakat perkotaan dan perdesaan. Hal ini tidak terlepas dari masih minimnya akses untuk pemerataan informasi, hal yang paling dirasakan adalah posisi geografi di Indonesia yang berbukit, serta masih rendahnya sebagian masyarakat dalam pendidikan terutama dalam pengetahuan di bidang teknologi.

Salah satu upaya pemerintah untuk mengatasi masalah tersebut, telah dikeluarkan kebijakan melalui Permen Kominfo No. 48/PER.M.KOMINFO/11/2009 tentang Penyediaan Jasa Akses Internet pada Wilayah Pelayanan Universal Telekomunikasi Internet Kecamatan.

Sesuai dengan perkembangan yang terjadi, Kemkominfo selanjutnya melakukan evaluasi terhadap Permen Kominfo No. 48/PER.M.KOMINFO/11/2009 tentang Penyediaan Jasa Akses Internet pada Wilayah Pelayanan Universal Telekomunikasi Internet Kecamatan dengan melakukan berbagai penyempurnaan terhadap pasal-pasal di dalamnya dan memberlakukan Permen Kominfo No. 19/PER.M.KOMINFO/12/2010, tentang Perubahan atas peraturan Menteri Komunikasi dan Informatika No. 48/PER/M.KOMINFO/11/2009, tentang Penyediaan Jasa Akses Internet pada Wilayah Pelayanan Universal Telekomunikasi Internet Kecamatan.

Dalam pasal 10b Permen Kominfo ini dijelaskan bahwa Pusat Layanan Internet Kecamatan (PLIK) yang bersifat bergerak adalah Pusat Layanan Internet Kecamatan yang memiliki kemampuan berpindah tempat (mobile) untuk menjangkau masyarakat yang belum terjangkau oleh layanan PLIK yang bersifat tetap di Wilayah Pelayanan Universal Telekomunikasi (WPUT) internet Kecamatan. Keberadaan MPLIK/PLIK dioperasikan oleh Balai Penyedia Pengelola dan Pembiayaan Telekomunikasi Informatika (BPPPTI), sedangkan untuk opersional di daerah dipercayakan kepada Diskominfo Kabupaten /Kota.

Tujuan program layanan internet ini diharapkan akan membantu masyarakat dalam hal pendidikan maupun peningkatan kesejahteraan masyarakat di perdesaan, para siswa bisa sejajar dalam penggunaan dan pemanfaatan internet dengan siswa di perkotaaan. Sehingga dengan adanya program ini diharapkan kesenjangan informasi yang terjadi di masyarakat dapat teratasi.

Model rekomendasi program yang telah dilakukan oleh Kemkominfo tersebut sepertinya telah komprehensif, tetapi hingga saat ini dalam implementasinya masih belum berlangsung optimal dan masih menyisakan banyak persoalan baik yang menyangkut kepentingan masyarakat maupun yang terkait dengan kemampuan institusi pelaksana di daerah. Kenyataan tersebut hingga saat ini menyebabkan institusi pelaksana dianggap belum optimal dalam mendorong tercapainya tujuan sebagaimana telah ditetapkan dalam kebijakan.

Fenomena yang muncul dalam pelaksanaan fasilitas Universal Service Obligation (USO) program Mobile Pusat Layanan Internet Kecamatan (MPLIK) dewasa ini menurut pengamatan penulis adalah kurang berhasilnya pelaksanaan kebijakan tersebut di daerah. Tujuan pemerintah untuk mengurangi kesenjangan informasi sebagaimana ditetapkan dalam kebijakan belum terlaksana dengan baik. Berbagai hambatan yang disebabkan adanya 
keterbatasan dari dinas itu sendiri, mulai dari masalah bahan bakar, kuota pulsa, biaya pemeliharaan, sampai masalah SDM serta birokrasi penyerahan melalui pihak ketiga seperti yang dikeluhkan oleh Dishubkominfo Kabupaten Sukabumi, yang tidak pernah merasa dilibatkan dalam pemberian bantuan MPLIK ini.

Berdasarkan uraian di atas, permasalahan dalam penelitian ini adalah bagaimanakah kebijakan Diskominfo Kabupaten Kuningan terhadap fasilitas USO program MPLIK di Kabupaten Kuningan?

Tujuan penelitian ini adalah untuk memperoleh pemahaman mendalam tentang kebijakan Diskominfo Kabupaten Kuningan dalam program MPLIK di Kabupaten Kuningan; Untuk mengetahui faktor-faktor yang menjadi pendukung dan penghambat dalam pelaksanaan kebijakan Diskominfo dalam mendukung Program MPLIK di Kabuparten Kuningan; Untuk mengetahui upaya-upaya yang dilaksanakan dalam pelaksanaan kebijakan Diskominfo dalam mendukung program MPLIK di Kabupaten Kuningan;

Kegunaan penelitian memberi masukan kepada Ditjen Penyelenggaraan Pos dan Informatika (PPI) Kemkominfo khususnya Balai Penyedia Pengelola dan Pembiayaan Telekomunikasi Informatika (BPPPTI) tentang pemanfaatan MPLIK di Kabupaten Kuningan

\section{LANDASAN KONSEP}

\section{Kajian Pustaka}

\section{Konsep Evaluasi Kebijakan Publik}

Secara umum evaluasi kebijakan menurut Anderson (1975) dapat didefinisikan sebagai: "Suatu kegiatan yang menyangkut penilaian atau pengukuran kebijakan termasuk isi, implementasi, dan dampaknya". Pandangan ini menunjukkan bahwa evaluasi kebijakan merupakan suatu kegiatan yang bersifat fungsional, dalam arti bahwa evaluasi kebijakan tidak hanya dilakukan pada tahap akhir melainkan pada seluruh proses kebijakan sehingga evaluasi kebijakan akan meliputi perumusan masalah-masalah kebijakan, program-program yang diusulkan untuk menyelesaikan masalah kebijakan, implementasi, maupun dampak kebijakan.

Dari sudut teknik pengukurannya, evaluasi merupakan cara-cara untuk menilai program-program pemerintah mulai dari teknik yang bersifat impresionistis (kesankesan observatif) sampai dengan teknik yang ilmiah dan sistematis dengan segala macam pedoman yang canggih.

Adapun dari sudut metode analisisnya yaitu bagaimana menggunakan informasi yang telah terkumpul dalam rangka menunjukkan hasil akhir (kesimpulan) dari kegiatan menilai program pemerintah tersebut, apakan program-program tersebut efektif atau tidak, memberikan dampak positif yang lebih besar dari dampak negatifnya atau sebaliknya.

Adapun sebagai langkah akhir dari kegiatan evaluasi adalah rekomendasi, yaitu penentuan mengenai apa yang harus dilakukan di masa yang akan datang.

Dalam konteks pertama, evaluasi dilakukan untuk melihat kembali, mengantisipasi atau menilai semua kemajuankemajuan yang dicapai pemerintah melalui kebijakan-kebijakan yang telah disusun dan diimplementasikan. Adapun yang kedua merupakan usaha dalam mengidentifikasikan metode-metode yang sistematis untuk menilai program-program pemerintah seperti metode eksperimental, perbandingan, replikasi atau analisis biaya keuntungan. Sedangkan menurut Suchman dalam Henry (1995) cakupan kegiatan evaluasi dan analisis cukup luas, aktivitas itu antara lain meliputi:

1. Mengidentifikasi tujuan program yang akan dievaluasi;

2. Analisis masalah.

3. Deskripsi dan standardisasi kebijakan;

4. Pengukuran terhadap perubahan yang terjadi;

5. Menentukan penyebab perubahan kebijakan atau penyebab lainnya di luar kebijakan;

6. Menentukan indikator-indikator keberadaan dampak kebijakan.

Tangkilisan (2003) dengan mengutip 
pada pendapat Edward III bahwa evaluasi kebijakan pada dasarnya adalah: "Membandingkan tujuan program dengan hasilnya, yang mengukur dampak program yang mungkin bisa diatribusikan pada kebijakan".

Evaluasi kebijakan mengharuskan dikumpulkannya informasi tentang implementasi dan dampak kebijakan. Tujuan lain dari evaluasi kebijakan adalah menghasilkan informasi yang bermanfaat untuk mengarahkan implementasi kebijakan menuju hasil yang lebih baik dan informasi perihal hubungan antara implementasi dan dampak kebijakan. Bila didasarkan pendapat Rossi dan Freeman (1985) penelitian tentang evaluasi merupakan:

"Aplikasi yang sistematis dari prosedur penelitian sosial dalam menilai konseptualisasi dan disain, implementasi, dan kegunaan dari program intervensi sosial. Dengan kata lain, penelitian tentang evaluasi melibatkan perencanaan, monitoring, efektivitas, dan efisiensi program pelayanan baik pada program kesehatan, pendidikan, kesejahteraan maupun program pelayanan lainnya"

atas $\begin{gathered}\text { Selain merupakan aktivitas penilaian } \\ \text { pelaksanaan program-program }\end{gathered}$ pemerintah maupun setelah dilaksanakannya suatu kebijakan, evaluasi kebijakan dapat dimulai dari tahapan perencanaan suatu program kebijakan, sebelum program dan pada saat kebijakan dilaksanakan. Evaluasi yang dilakukan sebelum kebijakan dilaksanakan merupakan kegiatan penting dalam kaitan dengan upaya efisiensi, penghematan-penghematan maupun usahausaha ekonomis lainnya

Mencermati konsep tersebut, maka evaluasi kebijakan sangat diperlukan tidak hanya untuk mengkaji keberhasilan kebijakan tersebut dalam memenuhi kebutuhan dan kepentingan masyarakat (public interest) akan tetapi menyangkut pula dengan efektivitas dan efisiensinya hasil kegiatan (output) yang nyata dan kemanfaatannya bagi keseluruhan pelaksanaan kebijakan. Dengan demikian, evaluasi dilakukan dalam rangka memperoleh hasil yang sebaik-baiknya melalui cara yang seefisien mungkin bagi masyarakat.
Kriteria pokok dari evaluasi kebijakan adalah sejauhmana keberhasilan telah diperoleh setelah pelaksanaan programprogram kebijakan. Tujuan evaluasi kebijakan adalah untuk memperoleh informasi yang akurat tentang derajat keberhasilan program dan kelancaran pelaksanaan program yang memungkinkan diketahuinya kelemahankelemahan dan kekurangan-kekurangan yang terdapat dalam program dan bagaimana cara memperbaikinya.

Evaluasi menghasilkan tuntutantuntutan yang bersifat evaluatif. Sehubungan dengan sifat utamanya tersebut, evaluasi menurut Dunn (2003) memiliki sejumlah karakteristik yang membedakannya dari metode analisis lainnya, di antaranya:

1. Value-Focus: Evaluation, as contrasted with monitoring, focuses on judgements regarding the desirability or value of policies and programs. Evaluation is primarily an effort to determine the worth or social utility of a policy or program, and not simply an effort to collect information about the anticipated and unanticipated outcomes of policy actions. Since the appropriateness of policy goals and objectives can always be questioned, evaluation includes procedures for evaluating goals and objectives themselves.

2. Fact-Value Interdependence: Evaluative claims depend as much on "facts" as they do on "values" To claim that particular policy or program has attained a high (or low) level of performances requires not only that policy outcomes are valuable to some individual, group, or society as a whole; it also requires that policy outcomes are actually a consequence of actions undertaken to resolve a particular problem. Hence, monitoring is prerequisite for evaluation.

3. Present and Past: Evaluative claims, as contrasted with advocative claims produced through recommendation, are oriented toward presente and past outcome, rather than future ones. Evaluation is retrospective and occurs after actions have been taken (ex-post). Recommendation, while also involving 
value premises, is prospective and occurs before action have been taken (ex-ante);

4. Value-Duality.: The values underlying evaluative claims have a dual quality, since they may be regarded as ends and as means. Evaluation is similar to recommendation in so far as a given value (for example, health) may be regarded as intrinsic (desirable in itself) as well as extrinsic (desirable because it leads to some other end). Values are often arranged in a hierarchy thet reflects the relative importance and interdependency of goals and objectives.

Evaluasi merupakan suatu usaha untuk menentukan manfaat atau kegunaan sosial suatu kebijakan atau program dan bukan sekedar usaha untuk mengumpulkan informasi mengenai hasil aksi kebijakan. Hal inilah yang membedakan evaluasi dengan monitoring. Monitoring dilakukan ketika sebuah kebijakan sedang diimplementasikan agar kesalahan-kesalahan awal dapat segera diperbaiki sehingga mengurangi risiko yang lebih besar. Evaluasi mencakup prosedur untuk mengevaluasi tujuan-tujuan dan sasaran kebijakan untuk menentukan bahwa kebijakan telah mencapai kinerja tinggi atau rendah dengan didukung oleh bukti bahwa hasil-hasil kebijakan secara aktual merupakan konsekuensi dari aksi-aksi yang dilakukan untuk memecahkan masalah tertentu. Sehubungan dengan hal tersebut, pemantauan (monitoring) merupakan prasyarat bagi evaluasi.

Tuntutan evaluatif diarahkan pada hasil sekarang dan masa lalu dibandingkan hasil di masa depan, karenanya evaluasi bersifat retrospektif dan setelah aksi-aksi dilakukan (ex-post), rekomendasi yang dihasilkan bersifat prospektif dan dibuat sebelum aksiaksi selanjutnya dilakukan (ex-ante). Nilainilai yang mendasari tuntutan evaluasi mempunyai kualitas ganda karena dipandang sebagai tujuan sekaligus cara. Evaluasi sama dengan rekomendasi sejauh berkenaan dengan nilai-nilai yang ada dan dianggap sebagai intrinsik (diperlukan bagi pencapaian tujuan) ataupun ekstrinsik (diperlukan karena hal itu memengaruhi pencapaian tujuan lain).
Fungsi dan Tujuan Evaluasi Kebijakan

Dunn (2003) menyatakan bahwa evaluasi kebijakan memegang sejumlah fungsi utama dalam analisis kebijakan, yaitu:

1. Memberikan informasi yang valid dan dapat dipercaya mengenai kinerja kebijakan yakni seberapajauh kebutuhan, nilai, dan kesempatan telah dicapai melalui tindakan publik dengan mengungkapkan seberapajauh tujuan tertentu dan target-target tertentu telah dicapai.

2. Fungsi selanjutnya adalah memberi sumbangan pada klarifikasi dan kritik terhadap nilai-nilai yang mendasari pemilihan tujuan dan target menyangkut kepantasan tujuan dan target dalam hubungan dengan masalah yang dituju.

3. Memberi sumbangan pada aplikasi metode analisis kebijakan lainnnya termasuk perumusan masalah dan rekomendasi. Informasi tentang tidak memadainya kinerja kebijakan dapat memberikan sumbangan pada perumusan ulang masalah kebijakan, misalnya dengan menunjukkan bahwa tujuan dan target perlu didefinisikan ulang. Evaluasi dapat pula menyumbang pada definisi alternatif kebijakan baru atau revisi kebijakan dengan menunjukkan bahwa alternatif kebijakan yang diunggulkan sebelumnya perlu dihapus dan diganti dengan kebijakan yang lainnnya.

Reeken dalam Henry menyatakan bahwa kegiatan evaluasi dapat dipergunakan untuk berbagai tujuan:

1. Membenarkan atau menguatkan suatu program secara berkelanjutan;

2. Menyelidiki atau audit program dalam rangka menilai kelemahan dan kegagalan,.

Gagasan evaluasi dalam kebijakan publik telah memasukkan ide dan teknik yang dikembangkan pada dunia bisnis, terutama memasukan Management By Objective (MBO), Human Resources Management (HRM) dan audit ke dalam manajemen sektor publik. Beberapa kalangan menyatakan bahwa kemunculan evaluasi dan audit pada 
pemerintahan dalam banyak hal telah melahirkan "negara evaluatif" baru dan memunculkan "masyarakat audit".

Dalam konteks anggapan kebijakan sebagai suatu urutan kegiatan, evaluasi kebijakan merupakan tahap akhir dari proses kebijakan. Evaluasi kebijakan dilakukan karena tidak seluruh program kebijakan publik dapat mencapai hasil sebagaimana yang diharapkan. Dalam kenyataannnya seringkali kebijakan publik gagal meraih maksud atau tujuan yang telah ditetapkan sebelumnya.

\section{Dimensi - Dimensi Evaluasi Kebijakan Publik}

Evaluasi kebijakan merupakan proses yang rumit dan kompleks karena selain melibatkan individu-individu yang terlibat dalam proses evaluasi juga melibatkan berbagai dimensi yang ditujukan untuk melakukan evaluasi.

Bardach, dalam Patton dan Sawicki (1986) mengemukakan empat (4) dimensi pokok dari evaluasi kebijakan yakni:

1. Kelayakan teknis (technical feasibility);

2. Peluang ekonomi dan finansial (economic and financial possibility);

3. Daya dukung politis (political viability);

4. Daya dukung administratif (administrative operability).

Technical feasibility: kelayakan teknis kebijakan. Menyangkut penyediaan informasi yang diperlukan untuk menilai keberhasilan program sehingga dapat diramalkan tentang kemungkinan pencapaian tujuannya. Pada konteks ini terdapat dua ukuran yakni efektivitas program adalah kemampuan tercapainya tujuan kebijakan dan adequacy adalah kemungkinan solusi pemecahan berdasarkan ketersediaan sumberdaya.

Economy and financial possibility: peluang ekonomi dan finansial. Mencakup biaya program dan keuntungan yang dihasilkan. Hal ini berkaitan dengan penilaian tingkat efisiensi suatu program. Program yang efisien adalah program yang mampu memberikan hasil atau benefit yang memadai ditinjau dari segi biaya dan keuntungan dari program tersebut. Ukuran untuk ini menyangkut tangible and intangible; monetarizable versus nonmonetarizable dan direct versus indirect cost benefit.

Political viability, kebijakan dibangun dalam arena politik karenanya harus cukup mendapatkan dukungan dari proses politik. Sebagai konsekuensinya, alternatif kebijakan selayaknya berfokus pada nilai-nilai/penilaian politis. Ukuran politis dalam hal ini berkaitan dengan didukungnya kebijakan oleh para pembuat keputusan (decision makers), para pejabat publik, masyarakat, dan lain lain sumber kekuasaan dalam proses politik. Secara spesifik hukum, perundangan dan aturan-aturan merupakan perwujudan dari padanya. Dengan demikian ukuran yang dimaksudkan menyangkut dukungan para penentu kebijakan yang memungkinkan dampak yang ditimbulkan atau kegunaan dari program-program kebijakan yang dihasilkan benar-benar berguna atau bernilai. Analisis tentang kriteria yang relevan untuk mengukur daya dukung politis sebagaimana dikemukakan Meltsner dalam Patton dan Sawicki (1986) menyatakan :"............ that should be considered in virtually every analysist include acceptability, appropriateness, responsiveness, legality and equity". Dengan demikian ukuran yang dapat digunakan untuk menilainya berkaitan dengan akseptabilitas, ketepatan, responsivitas, aturan, dan produk hukum yang mendukung serta keadilan baik bagi institusi maupun masyarakat.

Sebuah kebijakan mungkin saja memenuhi ukuran efektivitas dan efisiensi namun belum tentu memenuhi target dalam konteks kebutuhan dan keinginan dari klien/masyarakat. Karena itu keresponsifan merupakan indikator selanjutnya manakala sebuah kebijakan mengharapkan adanya dukungan secara politis.

Kewenangan yang dimiliki oleh institusi untuk mengadakan perubahan, menetapkan prioritas-prioritas program maupun melakukan require cooperation dengan institusi lain, merupakan kunci bagi keberhasilan dalam mengimplementasikan program-program suatu kebijakan. Kondisi ini menuntut adanya otoritas yang cukup 
besar dari sebuah institusi yang memungkinkannya untuk dapat melaksanakan perubahan-perubahan maupun pemilihan alternatif tindakan untuk menjalankan kebijakan sesuai dengan tuntutan yang diharapkan.

Komitmen institusi baik yang berasal dari atas maupun bawah dalam mendukung kebijakan sangat penting. Pada konteks ini tidak hanya kesungguhan pimpinan tetapi seluruh staf pelaksana yang terefleksikan pada perilakunya selayaknya mencerminkan komitmen tinggi akan terlaksananya kebijakan. Kemampuan yang mencakup staf maupun dukungan finansial untuk melaksanakan kebijakan sangat esensial dalam mengimplementasikan kebijakan. Keahlian (skills) teknis maupun administratif para pelaksana sangat dibutuhkan, begitu pula kapasitas finansial organisasi pelaksana. Mengidentifikasikan tentang hal yang memungkinkan terwujudnya kondisi eksisting dan perubahan yang memungkinkan sangat dibutuhkan untuk memfasilitasi kebijakan.

Organizational support atau dukungan sarana maupun prasarana untuk melaksanakan kebijakan merupakan kriteria penting lainnya, karena tidak hanya otoritas dan komitmen dari orang-orang penting saja yang dibutuhkan untuk melaksanakan kebijakan. Sangat penting kiranya untuk memiliki ketersediaan bangunan (sufficient equipment), fasilitas fisik serta support services lainnya. Jika kondisi ini tidak optimal maka tidak akan kondusif untuk mewujudkan ketercapaian tujuan kebijakan sebagaimana diharapkan.

\section{Kebijakan Fasilitas Universal Service Obligation (USO) Program MPLIK}

Perkembangan teknologi yang semakin pesat memberikan pengaruh yang sangat besar bagi perkembangan daerah, begitu pentingnya teknologi ini sehingga perkembangannya dapat dimanfaatkan oleh masyarakat, khususnya untuk mendapatkan dukungan informasi yang dapat mendukung aktivitasnya pada berbagai aspek kehidupan. Telekomunikasi dan informasi mempunyai peran yang strategis dalam menunjang dan mendukung kegiatan perekonomian masyarakat dalam memantapkan pertahanan dan keamanan serta mencerdaskan kehidupan bangsa.

Sehubungan dengan kepentingan masyarakat akan informasi ini, pemerintah melalui Kominfo telah merancang dan memberlakukan program layanan informasi di wilayah perkotaan maupun perdesaan melalui Permen Kominfo No. 48/PER/Undang-Undang Republik Indonesia No. 36 Tahun 1999 tentang Telekomunikasi dan Peraturan Menteri Komunikasi dan Informatika No. 32/PER/M.KOMINFO/10/2008 tentang Kewajiban Pelayanan Universal.

Melalui program tersebut seluruh masyarakat di lokasi pengadaan layanan diharapkan dapat memanfaatkan fasilitas ini, guna meningkatkan kesejahteraan dan perekonomian masyarakat di perdesaan, terutama dalam hal penciptaan jaringan komunikasi yang mudah, murah, dan cepat.

Salah satu manfaat yang bisa dinikmati dengan adanya program USO adalah terciptanya "Desa Pinter". Yaitu, desa yang telah terbangun jaringan komunikasi, tersedianya infrastruktur dan akses internet, serta adanya pemanfaatan infrastruktur tersebut secara tepat guna.

Kesenjangan digital atau digital devide, telah menjadi alasan utama pemerintah dalam pengembangan TIK di Indonesia, bahkan kesenjangan digital ini telah menjadi topik internasional dan telah diangkat ke forum internasional, dalam membahas digital devide di setiap negara khususnya di negara berkembang. Indonesia yang telah ikut dalam deklarasi WSIS (World Summit Information Society) di Geneva bulan Desember 2003 menyatakan kesiapannya untuk mendukung dan melaksanakan deklarasi tersebut. Di mana hasil dari deklarasi ini, diharapkan tahun 2015 seluruh wilayah perdesaan di dunia sudah tersambung dengan fasilitas jaringan komunikasi dan informasi termasuk internet.

Untuk mewujudkan action plan dari WSIS ini, di Indonesia diserahkan sepenuhnya pada Kementerian Perhubungan pada waktu melalui Dirjen Postel, untuk 
membangun jaringan telepon di perdesaan di seluruh tanah air, melalui program USO yang telah diresmikan di Jakarta pada tanggal 18 Desember 2003 (Satriya, 2004). Dengan terjadi perubahan politik pada waktu itu sejumlah kementerian mengalami perubahan strutur organisasinya, termasuk dimergernya Dirjen Postel dari Kementerian Perhubungan digabung ke Kementerian Komunikasi dan Informasi yang kemudian berubah kembali menjadi Kementerian Komunikasi dan Informatika yang kemudian berubah kembali struktur organisasi lembaga Kementerian Komunikasi dan Informatika ini menjadi Dirjen Perangkat Pos dan Informatika (PPI) yang mengelola pelaksanaan fasilitas USO.

Dalam perjalanannya istilah USO memang berasal dari sektor pertelekomunikasian yaitu pada sekitar tahun 1907, yang dipopulerkan oleh perusahaan telekomunikasi AT dan T, yang pada awalnya ditujukan untuk mempromosikan jasa pertelekomunikasian pada waktu itu melalui kebijakan subsidi silang (Mueller Jr, 1997).

Salah satu manfaat yang bisa dinikmati dengan adanya program USO adalah pemanfaatan MPLIK. Yaitu, pemanfaatan sarana kendaraan mobil untuk melayani daerah-daerah kecamatan yang belum terjangkau akses internet kecamatan, tersedianya infrastruktur dan akses, serta adanya pemanfaatan infrastruktur tersebut secara tepat guna.

\section{Kerangka Pemikiran}

Fungsi evaluasi dalam kebijakan publik dinyatakan oleh Dunn (2003) sebagai berikut: Pertama: Evaluasi memberi informasi yang valid dan dapat dipercaya mengenai kinerja kebijakan, yaitu seberapajauh kebutuhan, nilai dan kesempatan telah dapat dicapai melalui tindakan publik. Dalam hal ini, evaluasi mengungkapkan seberapajauh tujuan-tujuan tertentu dan target tertentu telah dicapai. Kedua: Evaluasi memberi sumbangan pada klarifikasi dan kritik terhadap nilai-nilai yang mendasari pemilihan tujuan dan target. Nilai diperjelas dengan mendefinisikan dan mengoperasikan tujuan dan target. Nilai juga dikritik dengan menanyakan secara sistematis kepantasan tujuan dan terget dalam hubungan dengan masalah yang dituju dengan menguji alternatif sumber nilai (kelompok kepentingan, klien) ataupun landasan dalam bentuk rasionalitas (teknis, ekonomis, legal, sosial, substantif). Ketiga: Evaluasi memberi sumbangan pada aplikasi metode-metode analitis kebijakan lainnya, termasuk perumusan masalah dan rekomendasi. Informasi tentang tidak memadainya kinerja kebijakan dapat memberikan sumbangan pada perumusan ulang masalah kebijakan dan definisi alternatif kebijakan yang baru atau revisi kebijakan dengan menunjukkan bahwa alternatif kebijakan yang diunggulkan sebelumnya perlu dihapus atau diganti dengan yang lain.

Mengacu pernyataan tersebut jelaslah bahwa meskipun pelaksanaan kebijakan merupakan proses yang berlanjut, tetapi pentahapannya perlu dilakukan dan evaluasi merupakan sesuatu yang berdiri sendiri meskipun tidak terlepas dari tahap yang mendahuluinya dan tahap yang segera mengikutinya.

Adanya kesenjangan akses informasi antara masyarakat di perdesaan dan perkotaan mendorong pemerintah untuk menyusun kebijakan layanan informasi publik berupa penyediaan layanan informasi di wilayah perkotaan maupun perdesaan. Kebijakan pemerintah dalam pelayanan informasi publik melalui Permen Kominfo No.19/PER.M.KOMINFO/12/2010, tentang Perubahan atas Peraturan Menteri Komunikasi dan Informatika No.48/PER/M. KOMINFO/11/2009, tentang Penyediaan Jasa Akses Internet pada Wilayah Pelayanan Universal Telekomunikasi Internet Kecamatan telah diimplementasikan di daerah oleh DISKOMINFO Kabupaten /Kota.

Tujuan dari kebijakan tersebut diharapkan akan membantu masyarakat, khususnya di perdesaan dalam hal:

1. Peningkatan pendidikan masyarakat;

2. Peningkatan kesejahteraan masyarakat;

3. Mengatasi kesenjangan informasi.

Dengan adanya kebijakan tersebut diharapkan masyarakat di perdesaan dapat 
menikmati jaringan komunikasi yang mudah, murah, dan cepat sehingga bisa mendorong terciptanya "Desa Pinter" yang memiliki jaringan, infrastruktur, dan akses komunikasi serta dapat memanfaatkannya secara tepat guna. Dengan demikian sebagian hambatan bagi kemajuan masyarakat perdesaan dalam pendidikan dan kesejahteraan dapat teratasi melalui pengetahuan dan pemahaman tentang teknologi informasi.

Berdasarkan uraian di atas, dapat di kemukakan batasan konsep sebagai berikut:

1. Evaluasi kebijakan adalah penilaian secara menyeluruh tentang efektivitas pencapaian sasaran suatu program atau penilaian efektivitas relatif dari dua atau lebih tujuan bersama.

2. Tujuan evaluasi kebijakan adalah untuk memperoleh informasi yang akurat tentang derajat keberhasilan program dan kelancaran pelaksanaan program yang memungkinkan diketahuinya kelemahankelemahan dan kekurangan-kekurangan yang terdapat dalam program dan bagaimana cara memperbaikinya.

3. Evaluasi kebijakan akan berlangsung efektif dengan memperhatikan dimensidimensi kelayakan teknis, dampak politis kebijakan, efisiensi atau manfaat kebijakan, serta aspek administratif pelaksanaan kebijakan.

4. Kebijakan MPLIK adalah perwujudan konsep pelayanan informasi publik dalam penyediaan jasa akses internet pada wilayah pelayanan universal telekomunikasi internet kecamatan yang memungkinkan terciptanya "Desa Pinter" yang telah memiliki jaringan infrastruktur dan akses informasi.

$\begin{array}{lcr}\text { 5. Memiliki } & \text { kemampuan } & \text { untuk } \\ \text { memanfaatkan } & \text { infrastruktur } & \text { tersebut } \\ \text { secara tepat guna. } & & \end{array}$

Berdasarkan kerangka pemikiran di atas, maka sebagai alur pikir penelitian dibuat skema bagan seperti terlihat pada gambar 2 .

\section{METODE PENELITIAN}

Metode yang digunakan dalam penelitian ini adalah deskriptif dengan jenis studi kasus. Pendekatan yang digunakan dalam penelitian ini adalah kualitatif yang memusatkan kepada fakta dan menggunakan analisis perbandingan.

Teknik pengumpulan data dalam penelitian ini disesuaikan dengan tujuan penelitian. Sumber data, pertama adalah para informan dan kondisi objek penelitian yang sesungguhnya, kedua adalah informasiinformasi dari berbagai literatur yang relevan dengan objek penelitian, baik berupa bukubuku, majalah, koran, jurnal partai maupun internet.

Untuk mendapatkan data yang lengkap peneliti menggunakan teknik pengumpulan data triangulasi (gabungan) yang bersifat menggabungkan dari berbagai teknik pengumpulan data dan sumber data yang telah ada. Dalam teknik triangulasi ini peneliti melakukan teknik pengumpulan data dengan tiga cara yaitu: observasi, wawancara terhadap informan yang mempunyai kaitan erat dengan permasalahan yang akan diteliti. Subjek penelitian adalah: Kepala Diskominfo sebagai penentu kebijakan proses penyelenggaraan tugas-tugas Bidang Kominfo di daerahnya. Perangkat Daerah (1 informan aparat Kesbang Linmas, 1 informan aparat kecamatan, 1 informan aparat desa, ketua RW, dan ketua RT), sebagai penyelenggaraan aparatur pemerintah daerah dalam pelayanan publik. 3 informan dari masyarakat, selaku sasaran kebijakan. Dokumentasi yakni berupa foto-foto yang berfungsi untuk memperjelas uraian pembahasan dan sebagai bukti pendukung.

Lokasi penelitian adalah di Kabupaten Kuningan, Provinsi Jabar.

Pengolahan dan analisis data dilakukan sejak pengumpulan data lapangan dengan alur sebagaimana gambar 3 .

Pengujian terhadap data dilakukan melalui uji validitas dan reliabilitas. Uji validitas dilakukan dengan memilah terlebih dahulu setiap informan yang akan digunakan sebagai sumber informasi dengan menggunakan pertimbangan kedalaman pengetahuan informan terhadap masalah MPLIK sebagai acuannya.

Adapun uji reliabilitas dilakukan 
dengan cara mengajukan pertanyaan yang sama kepada seorang informan namun dalam jangka waktu yang berbeda. Konsistensi jawaban informan terhadap pertanyaan yang sama tersebut dijadikan acuan bagi pengukuran reliabilitas data. Selain itu, penulis juga melakukan crosscheck data maupun informasi untuk menjaga reliabilitas dan validitas data dengan cara mengkonfrontir data dan informan satu dengan lainnya.

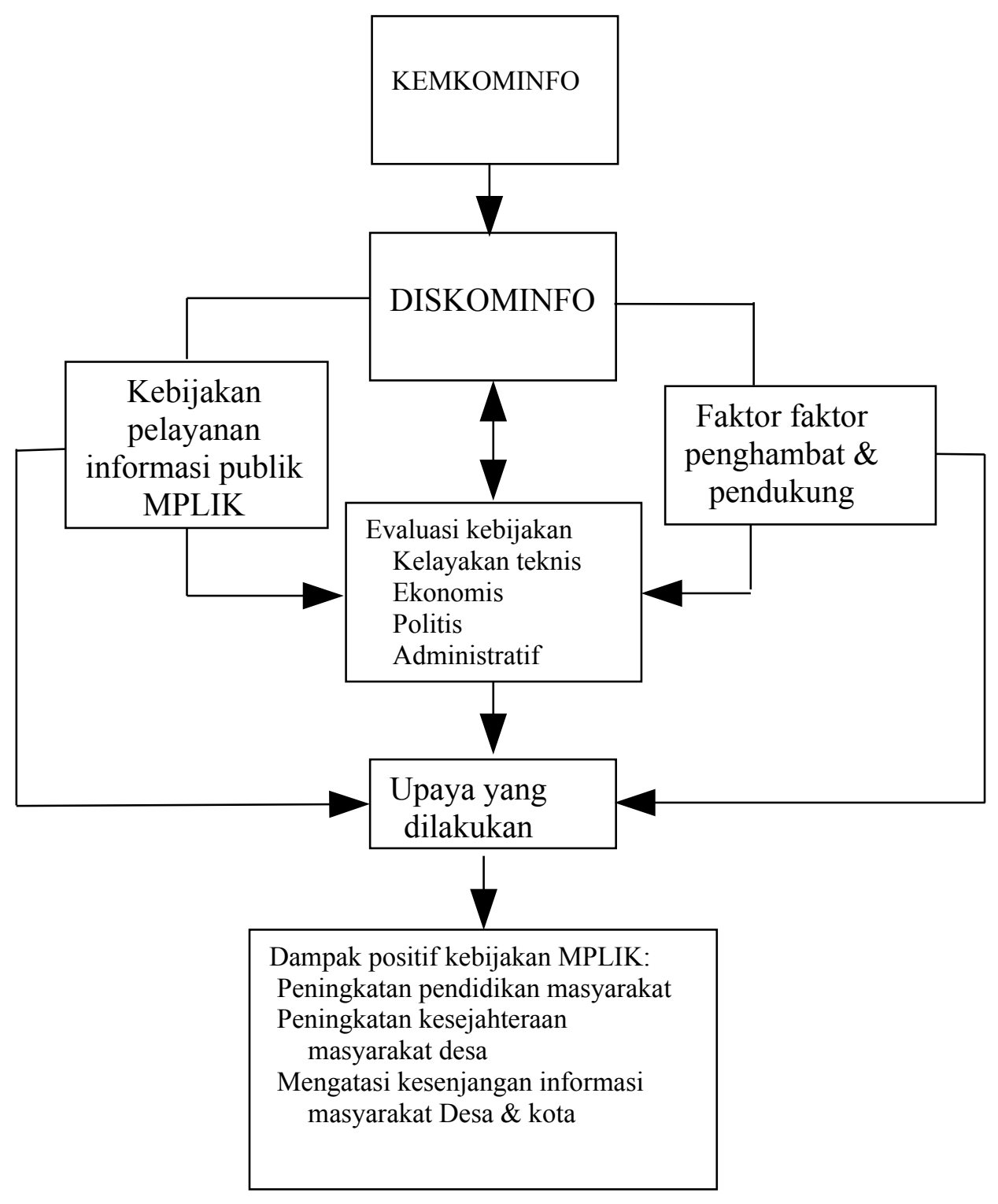

Gambar 2

Kerangka Pemikiran 


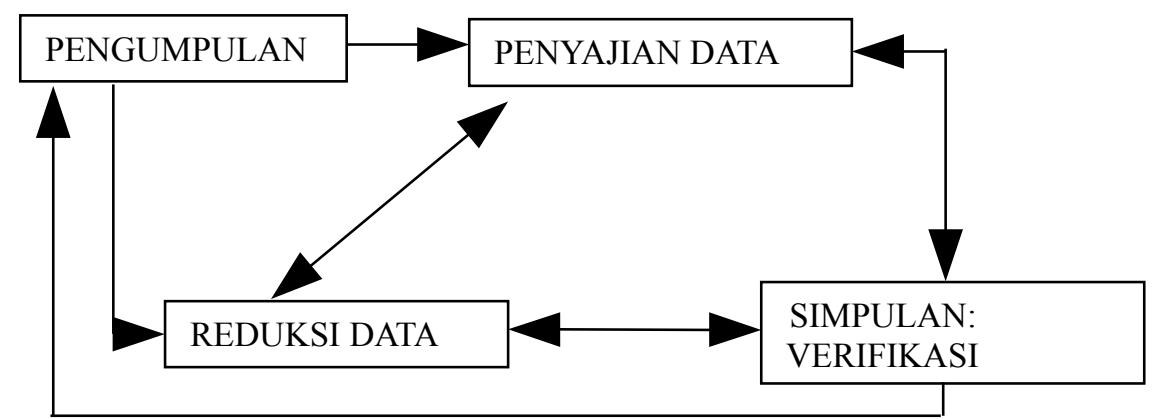

Sumber: Miles and Huberman 1992.

\section{Gambar 3}

\section{Analisis data Kualitatif}

\section{HASIL PENELITIAN DAN PEMBAHASAN}

\section{Hasil Penelitian \\ Evaluasi Kebijakan Penyediaan Fasilitas USO Program MPLIK di Kabupaten KuninganJabar}

Sesuai dengan perkembangan yang terjadi, Kemkominfo selanjutnya melakukan evaluasi terhadap Permen Kominfo No. 48/PER.M.KOMINFO/11/2009 tentang Penyediaan Jasa Akses Internet pada Wilayah Pelayanan Universal Telekomunikasi Internet Kecamatan dengan melakukan berbagai penyempurnaan terhadap pasal-pasal di dalamnya dan memberlakukan Permen Kominfo No.19/PER.M.KOMINFO/12/2010, tentang Perubahan atas Peraturan Menteri Komunikasi dan Informatika No. 48/PER/M.KOMINFO/11/2009, tentang Penyediaan Jasa Akses Internet pada Wilayah Pelayanan Universal Telekomunikasi Internet Kecamatan.

Hasil penelitian dan wawancara dengan informan di lapangan bahwa :

1. Pelayanan informasi melalui program MPLIK sudah tepat sasaran dan banyak dimanfaatkan oleh masyrakat. Hanya saja tidak bisa optimal dikarenakan masalah biaya dan perangkat yang tidak sesuai seperti perangkat Very Small Apertur Terminal (V SAT) yang tidak bisa dipakai karena kapasitas tidak sesuai.

2. Program kerja yang ditetapkan dinilai belum realistis, karena tidak didukung oleh pendanaan sehingga untuk melakukan mobilitas MPLIK ini tidak berjalan dengan baik, sehingga banyak lokasi di daerah tidak bisa terlayani, salah satunya adalah program yang diberikan Kemkominfo tidak tepat sasaran, karena diserahkan ke pengelola yang memang tidak kompeten dalam hal ini bukan suatu lembaga yang bertanggung jawab untuk mengelola MPLIK, mereka adalah masyarakat biasa yang tidak memilki akar pengelolaan yang baik, sehingga pengelola sendiri merasa kebingungan dalam mengelola MPLIK ini dikarenakan penghasilan dari hasil operasional MPLIK tidak mencukupi operasional selanjutnya.

3. Jika dihubungkan dengan kebutuhan kondisi sekarang ini MPLIK memang sangat memadai, karena sifatnya yang mobile tetapi pengelolaannya harus tepat dan dikelola oleh orang yang benarbenar mampu

4. Jika dilihat dari visi misi Kemkominfo sudah sesuai, tetapi pelaksanaan di lapangan sering berbeda dan sering kurang tepat, sehingga sering tidak tepat sasaran dalam pengembangan bidang kominfo di daerah

5. Standar Operasional Prosedur (SOP) MPLIK yang telah disusun dan telah disesuaikan dengan cakupan wilayah, tetapi dalam pelaksanaannya tidak sesuai dengan SOP, karena tidak jelasnya penunjukkan langsung yang seharusnya 
bisa melibatkan pemda setempat sebagai aparat yang mengetahui dan menguasai teknik di lapangan, sangat disayangkan pemberian MPLIK ini tidak tepat sasaran.

6. Juklak dan Juknis telah dilaksanakan dan sudah melalui sosialisasi, tetapi kenyataan di lapangan pihak pengelola tidak sanggup lagi untuk meneruskan program MPLIK ini dikarenakan kesiapan mereka dan tanggung jawab mereka untuk mengelola aset yang bernilai ratusan juta rupiah, sedangkan dari segi kemampuan pihak pengelola tidak mumpuni.

7. Aktivitas program MPLIK sementara ini diam di tempat artinya perangkat MPLIK tidak bisa mobile, dikarenakan tidaka adanya dana operasional, yang dalam ketentuan juklak dan juknisnya untuk operasional dibebankan kepada hasil dari opersional MPLIK, yang dalam kenyataannya dana hasil dari opersional ini jauh dari mencukupi, sehingga pihak pengelola mengambil keputusan untuk mengoperasionalkan MPLIK diam di tempat, juga tidak semua desa bisa menerima internet, karena perangkat $\mathrm{V}$ SAT yang sudah disediakan tidak bisa digunakan.

8. Program kerja yang sudah disusun tidak bisa mengatasi hambatan yang ada terutama dalam masalah dana operasional, saat ini pengelola hanya lebih bersifat mengamankan aset saja dan disimpan di tempat yang dinilai aman

9. Pada dasarnya untuk program kemitraan mereka belum jelas, karena arah jenis kemitraan belum ditentukan, bahkan pihak pengelola merasa berat untuk melanjutkan program MPLIK ini.

Dengan demikian Program MPLIK yang tujuannya untuk meningkatkan kesejahteraan dan perekonomian masyarakat di perdesaan, terutama dalam hal penciptaan jaringan komunikasi yang mudah, murah, dan cepat telah sesuai dan tepat sasaran.

\section{Pembahasan}

\section{Kelayakan Sosial dan Ekonomi}

Peluang ekonomi dan finansial. Mencakup biaya program dan keuntungan yang dihasilkan. Hal ini berkaitan dengan penilaian tingkat efisiensi suatu program. Program yang efisien adalah program yang mampu memberikan hasil atau benefit yang memadai ditinjau dari segi biaya dan keuntungan dari program tersebut. Hal tersebut diperkuat dari hasil penelitian di lapangan sebagai berikut :

1. Seharusnya ada subsidi dari pemerintah, karena rata-rata perhari apabila dioperasionalkan hanya dapat Rp40.000 perhari, sehingga biaya untuk operasional keliling saja tidak mencukupi, bahkan di lokasi lainnya pendapatan dari mengoperasionalkan MPLIK ada yang mendapat Rp20.000, hanya cukup untuk mengisi pulsa internet saja. Program MPLIK ini biaya sepenuhnya dibebankan kepada hasil operasional MPLIK. Sehingga apabila ada kerusakan terkadang menjadi tanggung jawab pengelola, bahkan salahsatu kendaraan MPLIK, teronggok di bengkel /dealer mobil Foton di Kota Cirebon, dan itu mobil baru yang baru beroperasi sekitar 3 bulan dari penyerahan.

2. Menurut pengelola pada waktu penyerahan dinilai tidak transparan, karena diserahkan oleh pihak ketiga spontanitas saja, tidak ada serah terima resmi termasuk membicarakan masalah anggaran untuk operasional MPLIK.

3. Secara ekonomis memang tidak menguntungkan karena kurangnya minat masyarakat dalam pemanfaatan internet, hal ini disebabkan mobil tersebut diopersionalkan secara statis/di tempat sehingga pengunjungnya hanya itu-itu saja, lain jika secara mobile, mungkin akan lebih banyak orang memanfaatkannya, hanya saja persoalan tidak bisa operasional secara mobile karena tidak adanya anggaran untuk operasioanal secara mobile.

4. Untuk mengefisiensikan biaya terpaksa dilakukan dengan diam di tempat, apalagi 
dari segi pendapatan hanya bisa untuk beli pulsa internet, yang penting program internetnya bisa jalan.

5. Kebijakan program MPLIK untuk saat ini baru bisa dirasakan keuntungan oleh masyarakat saja, sedangkan untuk pemerintah belum bisa, karena tidak optimalnya operasional MPLIK di lapangan.

Dengan demikian kontribusi fasilitas USO progran MPLIK bagi peningkatan kesejahteraan dan perekonomian masyarakat di perdesaan, terutama dalam jaringan komunikasi yang mudah, murah, dan cepat sudah signifikan.

\section{Daya Dukung Politis}

Hasil kebijakan atau program memberikan dampak terhadap masyarakat dan pembuat kebijakan. Dampak merupakan pengaruh yang ditimbulkan oleh suatu program. Kegiatan evaluasi bertujuan untuk menilai seberapajauh suatu program dapat memberikan pengaruh tertentu kepada sasaran. Dampak diukur berdasarkan kriteria keberhasilan sebagai indikator tercapainya tujuan program. Dengan demikian, tujuantujuan program hendaknya dibuat spesifik sehingga memungkinkan diamati dampaknya setelah program dilaksanakan. Sementara itu terdapat kemungkinan program menghasilkan dampak yang tidak diharapkan atau tidak sesuai dengan rencana yang ditetapkan. Hal tersebut diperkuat dari hasil penelitian di lapangan bahwa program MPLIK:

1. Belum ada keputusan baik pusat maupun daerah, artinya belum ada dukungan politik dalam program MPLIK ini baik pusat maupun daerah, sehingga keberadaan program MPLIK di daerah kurang mendapat dukungan karena secara administratif pun pihak Pemda tidak dilibatkan.

2. Belum terlihat adanya hubungan dengan situasi politik di Pemda Kabupaten Kuningan, hal ini disebabkan tidak adanya keterlibatan pihak Pemda dalam pengelolaan MPLIK ini, baik secara birokrasi maupun dalam sosialisasi
MPLIK sebelumnya.

3. Perubahan secara TIK sedikitnya telah membuka masyarakat setempat mengenal adanya penggunaaan internet secara mobile, tetapi sayang tidak bisa secara optimal dimanfaatkan, kendala utama tetap pada masalah anggaran untuk operasional.

4. Program MPLIK secara tidak langsung sangat mendukung terhadap lingkungan daerah, banyak masyarakat yang tidak tahu menjadi tahu, tapi sayang program ini tidak dapat dilaksanakan secara mobile, yang tadinya berharap dapat membuka wawasan masyarakat luas khususnya masyarakat di perdesaan.

5. Dukungan dari pemerintah daerah tidak ada. Karena pemda tidak dilibatkan dalam proses penyerahan bantuan MPLIK ini, bahkan pihak pemda sendiri dalam hal ini Diskominfo Kabupaten Kuningan mengakui tidak terlibat dalam penyerahan bantuan MPLIK ini.

Tujuan dari MPLIK dinilai sudah memenuhi rasa keadilan, dengan adanya program ini seluruh masyarakat sudah mampu menerima transfer ilmu, sehingga tidak ada lagi masyarakat yang tidak mengenal TIK. Dengan demikian kesenjangan digital sudah tidak ada lagi. Dari segi pelayanan kepada masyarakat untuk harga pemanfaatan MPLIK dinilai harganya sangat murah yaitu Rp2.000 perjam.

Dengan demikian dukungan politis terhadap regulasi di tingkat pusat, provinsi maupun daerah yang dapat memayungi aktivitas institusi pelaksana dalam menangani permasalahan yang timbul dalam pelaksanaannya di daerah sangat tinggi.

\section{Daya Dukung Organisasi}

Daya dukung organisasi menyangkut tentang seberapa mungkin program dilaksanakan sesuai kebijakan yang ada dan berdasarkan fakta-fakta yang ada bahwa daya dukung organisasi yang dilaksanakan di daerah kriteria yang dijadikan ukuran antara lain Otoritas, Komitmen Institusi, Kapabilitas 
Staf, dan Finansial, Fasilitas Fisik, dan lainlain dukungan.

Hasil penelitian menujukkan bahwa program MPLIK di daerah sangat didukung oleh masyarakat, hal ini dibuktikan hasil wawancara dengan informan yang menyatakan bahwa:

1. Penerima MPLIK ternyata bukan suatu lembaga yang dikelola oleh masyarakat, tetapi adalah masyarakat biasa pengelola wartel dan laundry yang diberi tanggung jawab untuk mengelola aset negara, yang akhirnya mereka tidak sanggup untuk mengelola lebih lanjut.

2. Secara perangkat sangat memadai, tetapi secara finansial tidak ada sama sekali, karena Pemda sebenarnya bisa dilibatkan dalam pengeloaaan MPLIK ini, sehingga scara finansial bisa turut mambantu kelangsungan MPLIK.

3. Begitu pula peran Provinsi dalam program ini, dukungan tidak memadai terbukti tidak ada pemantaun dalam pengelolaan MPLIK, apalagi dukungan dana tidak ada sama sekali.

4. Staf dalam pelaksanaan program MPLIK ini sangat tidak memadai karena seharusnya satu MPLIK dikelola oleh dua orang yaitu 1 orang operator dan 1 orang driver, tetapi kenyataan di lapangan hanya satu orang yaitu operator saja, bahkan ketiga MPLIK di Kabupaten Kuningan ini sekarang dikelola oleh satu orang saja, karena MPLIK yang satu mogok total dan disimpan di bengkel mobil di Kota Cirebon.

5. Untuk maintanance dilakukan oleh petugas PT. INFRA NET Bandung sedangkan, untuk petugas teknik jika darurat dilakukan oleh petugas free lance dari Kota Kuningan, sehingga apabila terjadi kerusakan MPLIK tidak bisa dijalankan karena teknisi dari pihak konsultan sering terlambat datang bila diminta.

6. Pelaksanaan program MPLIK yang dikelola oleh masyarakat sangat minim sumber keuangan, mungkin apabila dikelola oleh Pemda sebagai penanggung jawabnya akan lebih optimal karena pemda bisa menganggarkan untuk biaya operasioal MPLIK.

7. Pelayanan kepada masyarakat dapat dilaksanakan dengan apa adanya karena memang terbentur masalah biaya atau anggaran.

8. Dari prasarana institusi dinilai sudah cukup memadai dan telah sesuai dengan kebutuhan pelaksanaan tugas.

9. Berdasarkan kesepakatan yang tertuang dalam perjanjian memang dicantumkan setelah 4 tahun akan diserahkan ke Pemda tetapi dalam kurun waktu sekarang ini, pihak pengelola sudah merasa kewalahan dalam mengoperasikan MPLIK dan yang menjadi kendala utamanya tetap masalah anggaran.

10. Dalam pengelolaan MPLIK ini tidak ada koordinasi baik dengan Pemda setempat maupun lembaga masyarakat lainnya, hal ini disebabkan pihak pemerintah pusat maupun vendor /penyedia tidak melibatkan pihak Pemda maupun lembaga masyarakat, karena dari penyedia langsung ke penerima yang nota bene tidak memilki kemampuan untuk mengelola aset negara yang nilainya cukup tinggi.

\section{Hambatan-Hambatan Pelaksanaan Program}

Berdasarkan hasil penelitian ditemukan beberapa hambatan atau kendala dalam Penyediaan fasilitas USO program MPLIK di Kabupaten Kuningan Jabar sebagai berikut :

1. Secara teknis pemanfaatan perangkat jaringan internet $\mathrm{V}$ SAT tidak bisa digunakan karena untuk di daerah itu penerimaannya jelek, sehingga untuk sementara diganti dengan speedy Telkom, yang dibayar dari hasil rental MPLIK dari masyarakat pengguna MPLIK.

2. Hambatan finasial pengelola MPLIK tidak memilki anggaran untuk mengoperasionalkan secara optimal.

3. Dari segi dukungan pelaksanaan kebijakan tidak ada dukungan baik dari Pemda maupun dari para legislatif/eksekutif karena awalnya mereka tidak dilibatkan atau koordinasi 
dalam pelaksanaan pengelolaan MPLIK oleh masyarakat.

4. Hambatan sarana dan prasana tidak bisa berjalan dengan baik karena perangkat MPLIK diam di tempat tidak bisa beroperasional mobile secara penuh disebabkan tidak ada anggaran serta kualitas kendaraan sesuai dengan kondisi di lapangan bahkan salah satu mobil rusak total setelah digunakan secara mobile ke daerah-daerah.

\section{Upaya untuk Mengatasi Hambatan}

Upaya untuk mengatasi hambatan dalam penyediaan fasilitas USO program MPLIK di Kabupaten Kuningan Jabar terhadap hal-hal yang berhubungan masalah teknik masih ada garansi berupa maintanance dari pihak kontraktor MPLIK, yakni dari segi finansial pengelola mengupayakan sendiri biaya operasional MPLIK, dengan mengoperasikan MPLIK secara statis (diam). Dukungan politis tidak ada sama sekali karena secara birokrasi antara pemerintah pusat dalam hal ini Kemkominfo dan Pemda Kuningan tidak ada koordinasi masalah MPLIK ini.

\section{PENUTUP}

\section{Simpulan}

Pelaksanaan kebijakan Diskominfo Kabupaten Kuningan dalam program MPLIK yang tujuannya untuk meningkatkan kesejahteraan dan perekonomian masyarakat di perdesaan, terutama dalam hal penciptaan jaringan komunikasi yang mudah, murah, dan cepat telah sesuai dan tepat sasaran, belum terwujudkan secara optimal. Efektivitas program untuk meningkatkan kesejahteraan dan perekonomian masyarakat di perdesaan melalui penciptaan jaringan komunikasi yang mudah, murah, dan cepat belum sesuai dan tepat sasaran.

Dari segi ekonomi kebijakan MPLIK belum dapat memberikan keuntungan/benefit yang memberikan kontribusi langsung bagi kesejahteraan masyarakat. Standar Operasional Prosedur (SOP) MPLIK yang telah disusun dan disesuaikan dengan cakupan wilayah dalam pelaksanaannya tidak sesuai dengan SOP, karena tidak jelasnya mekanisme penunjukan langsung dalam pengelolaannya yang seharusnya bisa melibatkan Pemda setempat sebagai aparat yang mengetahui dan menguasai teknik di lapangan, sangat disayangkan pemberian MPLIK ini tidak tepat sasaran.

Dukungan politis terhadap regulasi di daerah yang dapat memayungi aktivitas institusi pelaksana dalam menangani permasalahan yang timbul dalam pelaksanaannya sangat kurang memadai. Daya dukung organisasi terhadap program MPLIK belum optimal khususnya dilihat dari indikator otoritas, komitmen institusi, kapabilitas staf dan finansial.

\section{Saran}

Untuk meningkatkan kelayakan teknis kebijakan sehingga pelayanan informasi melalui program MPLIK tepat sasaran dan banyak dimanfaatkan hendaknya dilakukan penyesuaian perangkat yang sesuai dengan daerah tujuan mengingat perangkat yang ada tidak dapat dioperasionalkan secara merata di daerah

Untuk meningkatkan daya dukung politis terhadap keberlangsungan program selayaknya dalam pengelolaan MPLIK melibatkan pemerintah daerah yang telah memahami karakteristik wilayah masingmasing sehingga dapat memberikan kontribusi dalam penunjukan pengelola maupun bantuan dana penyelenggaraan yang bersumberkan ABPD.

Untuk meningkatkan daya dukung organisasi perlu ditingkatkan dengan melibatkan stakeholders terkait dan partisipasi masyarakat yang memiliki perhatian dan kesungguhan.

Untuk mengatasi hambatan dukungan sarana maupun prasarana dalam melaksanakan kebijakan sangat penting kiranya untuk memiliki ketersediaan bangunan (sufficient equipment), fasilitas fisik serta support services lainnya 


\section{DAFTAR PUSTAKA}

\section{Buku :}

Agustiono, Leo. (2006). Politik dan Kebijakan Publik. Bandung: UNPAD, AIPI dan Puslit KP2W.

Anderson, James E. (1978). Public Policy Making. New York: Holt Rinehart and Winston.

Dunn, N. William. (2003). Pengantar Analisis Kebijakan Publik. Edisi kedua. Yogyakarta: Gajah Mada University Press.

Edward III, George C. (1980). Implementing Public Policy. Washington DC: Congressional Quarterly Press.

Faisal, Sanafiah. (1999). Metode Penelitian Kualitatif, Dasar Dasar Dan Aplikasi. Malang:YA3.

Henry, Nicholas. (1995). Public Administration and Public Affairs.. New Jersey Prentice hall Inc:Englewood Cliffs.

Irfan, Islamy. (2004). Prinsip-prinsip Perumusan Kebijakan Negara. Jakarta: Bumi Aksara.

Miles B Matthew dan Huberman A.Michael. (1992). Analisis Data Kualitatif. Penerjemah Rohendi Rohidi. Jakarta : UI Press.

Nogi Tangkilisan, Hessel. (2003). Evaluasi Kebijakan Publik. Yogyakarta: Penerbit Balairung \& Co.

Parsons, Wayne. (2005). Public Policy: Pengantar Teori dan Praktik Analisis Kebijakan. Alih bahasa oleh Tri Wibowo Budi Santoso. Jakarta:Kencana.

Patton, Carl V and Sawicki, David.S. (1986). Basic Methods of Policy Analysis and Planning. New York: Prentice Hall: Englewood Cliffs.

Rossi. P.H. dan H.E. Freeman. (1985). Evaluation A Systematic Approach $\left(3^{\text {rd }} d e\right)$ Beverly Hill CA:Sage.

Subarsono, AG. (2005). Analisis Kebijakan Publik (konsep, teori, dan aplikasi). Yogyakarta: Pustaka Pelajar.

Tangkilisan, Hessel. (2003). Evaluasi Kebijakan Publik. Yogyakarta:
Penerbit Balairung \& Co.

Wahab, Solichin Abdul. (2002). Analisis Kebijaksanaan Dari Formulasi Ke Implementasi Kebijaksanaan Negara. Jakarta. Bumi Aksara, Edisi 2.

Winarno, Budi. (2002). Teori dan Proses Kebijakan Publik, Media Pressindo Yogyakarta.

\section{Dokumen :}

Permenkominfo, No 48 /PER.M.KOMINFO//11/2009 Tentang Penyediaan Jasa Akses Internet Pada Wilayah Pelayanan Universal Telekomunikasi Internet Kecamatan . 12/1210, Tentang Perubahan atas peraturan Menteri Komunikasi Dan Informatika No.48/ PER/ M.KOMINFO/11/2009, Tentang Penyediaan Jasa Akses Internet Pada Wilayah Pelayanan Universal Telekomunikasi Internet Kecamatan.

\section{Internet:}

MPLIK (Mobile Pusat Layanan Internet Kecamatan). (2012). USO: Latar Belakang. Tersedia dalam $<$ http://www.mplik-paket5.com/tentanguso/pengertian/latar-belakang/item/133uso-latar-belakang.html>. Diakses tanggal12 April 2013.

Mueller, Milton,L,Jr. (1997). Competition, Interconection, and Monopoly in Making of The American Telephone System. Tersedia dalam (www.fclj.org/wp.conten/../1997/01/Miller.Pdf). Diakses tanggal 12 April 2013.

Satriya, Eddy. (2004). USO Telekomunikasi: Majalah Bisnis Komputer No. 03 Edisi Maret 2004. Tersedia dalam $<$ www.bappenas.go.id/get-fileserver/node/2766/universal-service-obligation-uso---oleh-eddysatriya_20081123135217_7_2.pdfUSO.pdf>. Diakses tanggal 12 April 2013. 